\title{
PUBLIC PERCEPTION OF COMMUNITY PHARMACISTS IN SOUTH AFRICA: A PRELIMINARY STUDY
}

\section{Suzanne Bornman}

M Pharm, Registered Pharmacist

Ph D student, Department of Pharmacy, Nelson Mandela Metropolitan University (NMMU)

\section{Ilse Truter}

D Com, B Pharm, M Sc \& Ph D, Registered Pharmacist

Associate Professor and Head of Pharmacy Practice, Drug Utilization Research Unit (DURU), Department of Pharmacy, Nelson Mandela Metropolitan University (NMMU)

Corresponding author: Ilse.Truter@nmmu.ac.za

\section{Daniel JL Venter}

M Sc, Statistician

Senior Lecturer, Department of Mathematical Statistics, Nelson Mandela Metropolitan University (NMMU)

Keywords: community (retail) pharmacy; perception; pharmacists; over-the-counter (OTC) medicine; self-medication

\begin{abstract}
This survey forms part of a study undertaken to identify and quantify the community pharmacist's involvement in the use of non-prescription/over-the-counter (OTC) medicine/self-medication in community pharmacies throughout South Africa. The objectives of this study were to establish the public's perception of the role of and the value added by community pharmacists in the treatment of minor ailments. A survey was conducted amongst 300 consumers prior to the recent changes and introduction of new legislation affecting pharmaceutical care and the dispensing of medicine. The major finding of this study was that the majority of consumers who consulted community pharmacists were satisfied with the comprehensiveness of the counselling and the effectiveness of the treatment provided. A large majority of the participants agreed that community pharmacists play a positive role and add value. It was found that the main reason for visiting a specific pharmacy was the proximity of that pharmacy.
\end{abstract}

\section{OPSOMMING}

Hierdie opname vorm deel van 'n studie wat onderneem word om die gemeenskapsapteker se betrokkenheid in die gebruik van nie-voorskrif/oor-die-toonbank medikasie/selfmedikasie in gemeenskapsapteke in Suid Afrika te identifiseer en te kwantifiseer. Die doelwitte van hierdie studie was om die publiek se persepsie oor die rol en waardetoevoeging van die gemeenskapsapteker tot die behandeling van minder ernstige siektetoestande te bepaal. 'n Opname is geloods onder 300 kliënte voor die onlangse veranderings en bekendstelling van nuwe wetgewing aangaande farmaseutiese sorg en die reseptering van medisyne. Die belangrikste bevinding van die studie was dat die meerderheid van kliënte wat gekonsulteer is deur gemeenskapsaptekers, tevrede was met die volledigheid van die raadgewing en die effektiwiteit van die behandeling voorsien. Die meerderheid van die deelnemers het saamgestem dat gemeenskapsaptekers 'n positiewe rol speel en waarde toevoeg. Die hoofrede waarom 'n spesifiekte apteek besoek word, was die gerieflike ligging van daardie apteek. 


\section{INTRODUCTION}

Worldwide governments are increasingly trying to wean their citizens away from total reliance on the state for health care and are encouraging people to take care of themselves when this is appropriate. As a consequence, self-care has become an important part of the health care system (Levin, 1990:150).

One way of encouraging greater self-care is through responsible self-medication (Krishman \& Schaefer, 2000:102). The high prevalence of self-medication is demonstrated by the continuous growth of consumers' self-awareness and self-reliance and their escape from the dependency and alienation brought about by medicalisation (Van der Geest \& Hardon, 1990:199). Bezold (1990:205) also documented a new attitude towards health, including increased self-responsibility for health. Health professionals have had to change their attitudes from being authoritative and making all the decisions on behalf of the patient, to playing a consultative role, informing and advising the patient and his or her family so that they are able to make many of the decisions themselves (Lunde, 1990:150). Other reasons for increased usage of self-medication are the increasing amount of health care literature now available to the public, and the deregulation of a number of agents from prescription-only medicine status to pharmacy-medicine status (McElnay \& McCallion, 1996:6).

As the population becomes better educated with the ease of retrieval of information from the Internet, it is not surprising that consumers are beginning to take more interest and feel more confident in managing their own health. Nevertheless, the explosion of information can make it difficult for consumers to make a proper and safe decision when choosing self-treatment. Therefore community pharmacists must play the role of gatekeeper to proper and safe use of self-medication and this advice should be readily available (Chui \& Li, 2005:225).

Furthermore, the over-the-counter (OTC) range now encompasses drugs which have previously, on prescription, been used for potentially more serious and longer term conditions. Some of the more recently deregulated medicines $\left(\mathrm{H}_{2}\right.$-antagonists, for example) may at first not seem to be natural choices for OTC use. However, formulations, dosages, and licensed indications for drugs that become available over the counter are not necessarily the same as those which pertain to its use as a prescription only preparation. These deregulation processes place a great emphasis on the provision of appropriate information to the patients (Bradley \& Blenkinsopp, 1996:835).

Responsible self-medication may be defined as the rational use of designed, labelled and authorised medication for self-care. These medications are legally classified as non-prescription drugs (also known as overthe-counter (OTC) drugs or self-medication). The control of medicines and scheduled substances in South Africa is described in Section 22A of the Medicines and Related Substances Act 101 of 1965 (2003:MAE21-MAE-28). That the use of non-prescription drugs has become an integral part of the health care system is well documented by the constantly growing sale of these medicines (Krishman et al. 2000:102).

OTC medication or self-medication can be defined as medication that can be:

- applied or taken to relieve symptoms of selflimiting ailments, without a prescription;

- taken to prevent an illness;

- taken to maintain good health or supplement a diet; and

- taken to cure an illness without a prescription (Ong, 1990:225).

In South Africa these OTC medications can be divided into pharmacy-only drugs (S1 and S2 registered medication), and the rest (SO and unregistered drugs, for example supplements, vitamins and complementary medicines) which can be found in pharmacies as well as supermarkets, health food shops, health and beauty shops, convenience stores and ethnic herbalists. For the purpose of this study, self-medication was defined as the OTC medication provided by the pharmacist in the retail or community pharmacy for the treatment of minor illnesses, described as symptoms by the patient. A retail or community pharmacy in South Africa refers to a pharmacy wherein or from which some or all of the services as prescribed in regulation 18 of the Regulations Relating to the Practice of Pharmacy are provided to persons requiring pharmaceutical services, but excludes an institutional pharmacy (Regulations Relating to the Registration of Persons and the Maintenance of Registers, 2003:PRE-76). 
Pharmacies are part of the overall health care system and pharmacists are authorised health care practitioners performing their profession under strict regulations. Good Pharmacy Practice in South Africa (2004:4) describes the core of pharmacy activity as the supply and distribution of medicines and other health care products, the provision of appropriate information and advice to the patient, ensuring the correct use of medicine and monitoring the effects of the use of medicine (pharmaceutical care). One of the objectives of the South African Pharmacy Council is also to promote the provision of pharmaceutical care which complies with universal norms and values, in both the public and private sector, with the goal of achieving definite therapeutic outcomes for the health and quality of life of a patient (Pharmacy Act 53 of 1974:PAE-8). The current medicine distribution system through pharmacies pays particular attention to issues of drug safety. The argument for keeping all medicines in pharmacies makes sense due to the fact that nonprescription medicines are not without adverse effects, nor free from potentially dangerous interactions with other medicines (Krishman et al. 2000:103). Authoritative information on proper use is vital, and the community pharmacist is a good source for that. As the primary professional support to self-care and a promoter of general good health, the pharmacy stands centrally placed in the development and execution of effective self-care practice (Lunde \& Dukes, 1989:3).

Unlike prescription medicines, where learned intermediaries facilitate access, consumers must often rely on their own judgement when selecting OTC products. These decisions are usually formed through imperfect reference sources such as advertisements, friends, relatives and also labels, which are often hard to read and difficult to understand. Choosing an OTC product is therefore often an overwhelming task for consumers, given the multitude of choices within therapeutic classes, as well as between brand names, generics or private label products (Alsobrook, 1992:317).

It is widely recognised that pharmacists undertake an important care role in advising the public on the management of common ailments and health problems. Community pharmacists are frequently the first, and often the only, health professionals who are consulted by the public on what are often perceived to be minor ailments (Smith, 1996:30). The pharmacist's role in OTC or self-medication needs to be the facilitation of safe and effective use of these non-prescription/OTC medications. If patients are to make sensible decisions, they need to be advised. The pharmacist is ideally positioned in the community to fulfil this role as a health information resource. The pharmacist is appropriately qualified and accessible (Bell, 1990:221).

Pharmacists, as the primary source of drug supply, play a key role in counselling patients on their medication in order to monitor the use of non-prescription medicines, to identify drug related problems and to intervene when necessary, to ensure that patients use medicines safely, appropriately and effectively (Berger, Eickhoff \& Schulz, 2005:45). It is also the responsibility of pharmacists to refer patients to other health care professionals if the condition or severity of the condition warrants it.

The most significant characteristic of community pharmacists is their accessibility. They are available to the public throughout the working day with no appointments, no receptionists and no direct charges - therefore with no barriers for help seekers (Reekie \& Scott, 1988:205). The ease of access to a retail pharmaceutical outlet means that it is often the first point of contact for people in need of advice or information about medical care (Mukerjee \& Blane, 1990:1277).

There are only a few studies that have illuminated the value of pharmacy-based self-medication and a class of pharmacy-only OTC drugs. Additionally, few studies have been reported that concomitantly evaluated the quantity and quality of pharmacy advice and the outcomes of self-medication and the advice given on the patient level (Krishman et al. 2000:102).

Dreyer and colleagues (1999:3) conducted a study in South Africa with the objective of measuring the cost savings effected by community pharmacists' interventions in the supply of medicines in South Africa. One of the objectives focussed specifically on the incidence and extent of interventions made by community pharmacists in the supply and use of non-prescription (OTC) medicines and the promotion of self-care. The outcomes of pharmacist-initiated therapy in the treatment of minor illnesses were also measured. The results indicated that of all the OTC/self-care requests received by pharmacists, $78.2 \%$ were for the treatment of a particular 
condition, while only $40.6 \%$ were product related. This corroborates the view that the community pharmacy is often the first port of call for the treatment of, or advice about, minor illnesses. The most frequently treated conditions were respiratory (37.8\%) and gastrointestinal (14.1\%). In response to the treatment of minor illnesses, pharmacists recommended OTC products in $74.8 \%$ of cases, while $8.4 \%$ of cases were referred. Of the patients treated by pharmacists for minor illnesses, $62.9 \%$ reported a vast improvement, $30.1 \%$ experienced some improvement, $4.5 \%$ indicated that no change took place and $2.5 \%$ claimed that their condition worsened. Only $10.2 \%$ of patients treated considered it necessary to visit a doctor (Dreyer, Serfontein, Van der Meer \& Wagner, 1999:12).

Given the limited number of recently published research on how patients perceive their community pharmacist and pharmacy in South Africa, this study was initiated as a preliminary study into an area that without doubt warrants more in-depth research.

The specific objectives for this study were to determine:

- $\quad$ patients' satisfaction levels with the services rendered by the community pharmacist;

- why patients do or do not make use of the community pharmacist for treatment of minor illnesses;

- the comprehensiveness of the pharmacist's consultation process;

- patients' perceptions of the effectiveness of the pharmacist's diagnosis and medication provided;

- patients' perceptions of the role and value of the community pharmacist in health care; and

- reasons why patients are using a specific pharmacy.

\section{METHODOLOGY}

This study forms part of a bigger study that focuses on the community pharmacist's involvement in non-prescription (over-the-counter or OTC) medicine provided by community pharmacies throughout South Africa. To obtain information regarding the perceptions and attitudes of the public in this regard, a telephone survey was conducted. The sample size (N) was 300 individuals. A second survey will be conducted at a later stage after the effects of the recent introduction of new regulations affecting the pharmaceutical industry and dis- pensing have stabilised. The reason for using a research design with two surveys is to determine the impact of these new regulations on the perceptions of patients regarding pharmaceutical care. The second survey will be conducted after the market has settled down, and the pharmaceutical industry is more stable.

The sample for this survey was stratified according to the population size per province and randomly selected to be representative of all nine provinces of South Africa (see Table 1). The official telephone directories of the different provinces/areas were used to randomly select the patients. The height of the telephone directory was measured (in $\mathrm{cm}$ ), and divided into the number of patients required for the sample. On a specific page selected, a telephone number was randomly selected. Should that telephone number have no longer existed, or the individual did not agree to participate, the next number was used.

The survey was conducted during two weeks in March 2004. The telephone calls were handled by the University of Port Elizabeth Health and Development Research Institute (the name of the university has since changed to the Nelson Mandela Metropolitan University). Field workers were briefed on the details of the project. All the participants were telephonically contacted between 17:30 and 20:00 each day, to ensure that most of the individuals were available at home. If a person could not be reached after two telephone calls, the next number on the selected page was used.

The questionnaire that was used for the survey is given in Appendix A. Summated scores were calculated for each of the following sections of the questionnaire: $D$ Consultation; E-Medication; and F-Pharmacist and Pharmacies.

The scores, calculated as the mean of the questions in each section, were labelled DScore, EScore and FScore respectively. Factor analyses were conducted for each section to determine which items, if any, should be included in the respective summated scores and Cronbach's coefficient alphas were calculated to determine the reliability of the summated scores (see Table 4 for the calculated values). The questionnaire in Appendix A was developed by the researchers (it was not based on any previously used or a previously tested questionnaire) and since the study is a preliminary 
Table 1: Distribution of participants according to province

\begin{tabular}{|l|c|}
\hline \multicolumn{1}{|c|}{ Province } & Number \\
\hline Eastern Cape & 28 \\
\hline Free State & 16 \\
\hline Gauteng & 97 \\
\hline KwaZulu-Natal & 54 \\
\hline Limpopo & 10 \\
\hline Mpumalanga & 12 \\
\hline North West & 12 \\
\hline Northern Cape & 9 \\
\hline Western Cape & 62 \\
\hline Total & 300 \\
\hline
\end{tabular}

Table 2: Age distribution of participants

\begin{tabular}{|l|c|c|}
\hline \multicolumn{1}{|c|}{ Age Group (in years) } & Number & Percentage \\
\hline $15-19$ & 15 & $5.1 \%$ \\
\hline $20-29$ & 45 & $15.3 \%$ \\
\hline $30-39$ & 58 & $19.7 \%$ \\
\hline $40-49$ & 65 & $22.0 \%$ \\
\hline $50-59$ & 46 & $15.6 \%$ \\
\hline $60-69$ & 34 & $11.5 \%$ \\
\hline $70-79$ & 25 & $8.5 \%$ \\
\hline $80-87$ & 7 & $2.4 \%$ \\
\hline Total & 295 & $100 \%$ \\
\hline
\end{tabular}

Table 3: Highest education level of participants

\begin{tabular}{|l|c|c|}
\hline \multicolumn{1}{|c|}{ Level } & Frequency & Percentage \\
\hline Pre-school & 5 & $1.8 \%$ \\
\hline$<$ Grade 6 & 18 & $6.4 \%$ \\
\hline$<$ Grade 12 & 60 & $21.3 \%$ \\
\hline Grade 12 & 119 & $42.2 \%$ \\
\hline Diploma/Degree & 80 & $28.4 \%$ \\
\hline Total & 282 & $100 \%$ \\
\hline
\end{tabular}

study, validity can only be confirmed by the fact that a pilot study was conducted and that it was found that the measuring instrument measured what it was intended to measure.
A limitation of this study was the fact that only individuals with telephone numbers listed in the provincial telephone directories were included in this study. Telephone interviews were conducted in English only. 


\section{RESULTS}

\section{Demographic characteristics of partici- pants}

A total of 300 consumers were telephonically contacted. Only 279 (93.0\%) of the participants were prepared to give their gender. Nearly two-thirds (63.8\%) of participants were female. The age distribution of participants is given in Table 2 .

The youngest participant was 15 years old and the oldest 87 years, with a median age of 43 years.

Table 3 indicates the highest education level of the participants. The majority $(70.6 \%)$ of the participants had at least a grade 12 qualification. Eighteen participants did not answer this question.

Most of the participants $(62.0 \%$, or 183 participants) belonged to a private medical aid scheme. Of those that were members of a medical aid scheme, the majority $(56.7 \%)$ had an over-the-counter (OTC) option.
The distribution of patients who made use of their medical aid OTC option is indicated in Figure 1.

As described in the Methodology, summated scores were calculated for each section of the questionnaire. Table 4 summarises how the scores were calculated and reports Cronbach's alpha coefficients ranging from 0.77 to 0.94 which were all above the recommended minimum level of 0.70 . This confirms the reliability of the summated scores.

\section{Use of the pharmacist for the treatment of minor ailments}

Nearly $55 \%(54.8 \%)$ of consumers indicated that they consult their pharmacist for the treatment of minor ailments. Table 5 indicates the reasons given by the 135 $(45.2 \%)$ respondents who did not make use of the pharmacist for the treatment of minor ailments.

The majority of these participants preferred to get their medication from either the doctor (67.9\%) and/or the clinic $(55.2 \%)$.

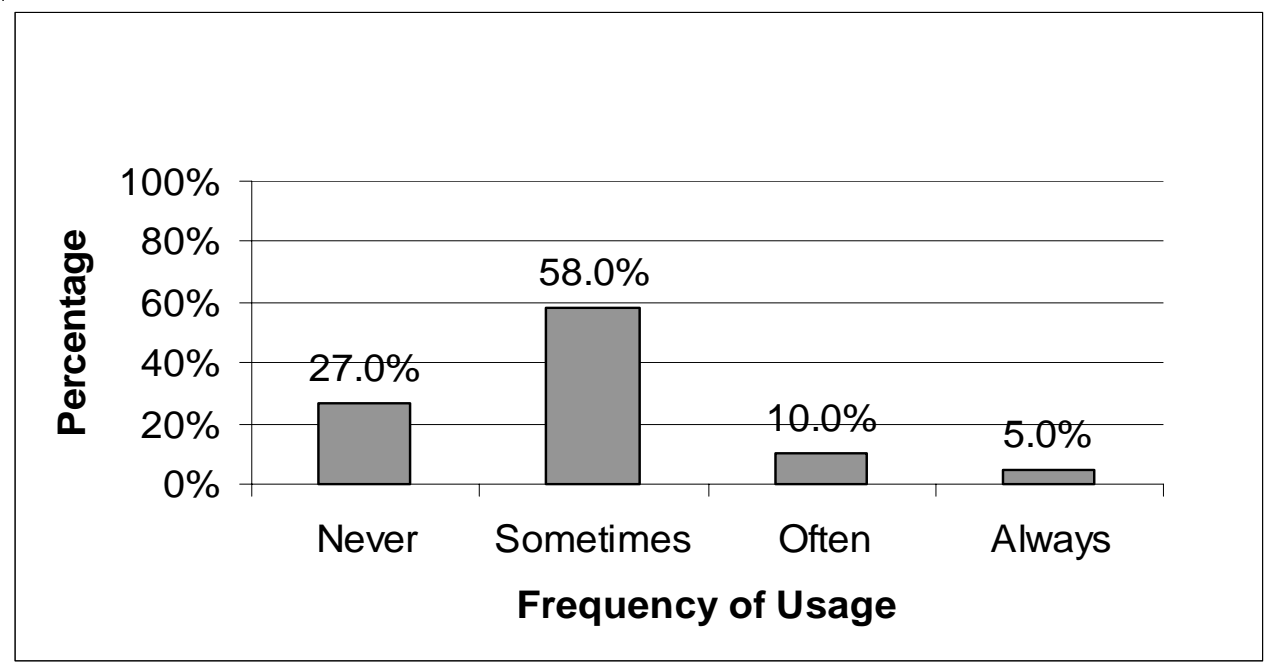

Figure 1: Usage of medical aid OTC option

Table 4: Reliability of the Summated scores for Sections D, E and F

\begin{tabular}{|l|c|c|c|}
\hline \multicolumn{1}{|c|}{ Section } & Questions & $\begin{array}{c}\text { Summated } \\
\text { Score }\end{array}$ & $\begin{array}{c}\text { Cronbach's } \\
\text { alpha }\end{array}$ \\
\hline D Consultation & 1 to 8 & DScore & 0.90 \\
\hline E Medication & 2 to 4 & EScore & 0.77 \\
\hline F Pharmacists \& Pharmacies & $\begin{array}{c}1 \text { to } 11 \text { (questions 4, 5 } \\
\& 8 \text { inverted) }\end{array}$ & FScore & 0.94 \\
\hline
\end{tabular}


Table 5: Reasons why patients did not use pharmacists for treatment of minor ailments

\begin{tabular}{|l|c|c|}
\hline Reason & Frequency & Percentage \\
\hline Get medication from the doctor & 91 & $67.9 \%$ \\
\hline Get medication from the clinic & 74 & $55.2 \%$ \\
\hline Pharmacy too expensive & 29 & $21.6 \%$ \\
\hline Get it on medical aid - need a prescription to claim & 27 & $20.1 \%$ \\
\hline Get medication from the supermarket & 14 & $10.4 \%$ \\
\hline Doctors are better qualified to treat & 11 & $8.2 \%$ \\
\hline Does not have access to a pharmacy & 7 & $5.2 \%$ \\
\hline Does not like a pharmacist & 5 & $3.7 \%$ \\
\hline Does not see it as part of the scope of a pharmacist & 5 & $3.7 \%$ \\
\hline Doctor easily accessible - closer & 2 & $1.5 \%$ \\
\hline Does not trust pharmacist & 2 & $1.5 \%$ \\
\hline Get medication from a traditional healer & 2 & $1.5 \%$ \\
\hline Have a healthy family & 2 & $1.5 \%$ \\
\hline Doctor prescribes better medicine & 1 & $0.7 \%$ \\
\hline Does not trust anybody & 1 & $0.7 \%$ \\
\hline Pharmacist is not that professional & 1 & $0.7 \%$ \\
\hline Qualified as a nurse & 1 & $0.7 \%$ \\
\hline
\end{tabular}

Table 6: Perceptions of participants regarding the pharmacists' consultation

\begin{tabular}{|l|c|c|c|}
\hline Comments & $\begin{array}{c}\text { Yes, very } \\
\text { good }\end{array}$ & $\begin{array}{c}\text { Yes, but not } \\
\text { satisfactory }\end{array}$ & $\begin{array}{c}\text { No, not at } \\
\text { all }\end{array}$ \\
\hline Explain how to use medication & $92.7 \%$ & $5.5 \%$ & $1.8 \%$ \\
\hline The correct diagnosis & $90.7 \%$ & $7.5 \%$ & $1.9 \%$ \\
\hline Refer to doctor if symptoms persist & $82.8 \%$ & $11.7 \%$ & $5.5 \%$ \\
\hline Asked about allergies & $82.2 \%$ & $11.0 \%$ & $6.7 \%$ \\
\hline Asked on chronic conditions & $80.4 \%$ & $12.9 \%$ & $6.7 \%$ \\
\hline Explained special precautions & $80.4 \%$ & $11.7 \%$ & $8.0 \%$ \\
\hline Asked about other medication usages & $80.2 \%$ & $13.0 \%$ & $6.8 \%$ \\
\hline Explained possible side effects & $79.1 \%$ & $12.9 \%$ & $8.0 \%$ \\
\hline
\end{tabular}

Table 7: Average consultation time and time since last consultation

\begin{tabular}{|l|c|c|c|c|c|c|}
\hline & N & Mean & S.D. & Min. & Median & Max. \\
\hline $\begin{array}{l}\text { Average consultation time (in } \\
\text { minutes) }\end{array}$ & 146 & 8.47 & 8.14 & 1.00 & 5.00 & 60.00 \\
\hline $\begin{array}{l}\text { Time since last consultation (in } \\
\text { months) }\end{array}$ & 62 & 2.22 & 2.48 & 0.10 & 1.00 & 12.00 \\
\hline
\end{tabular}




\section{Consultation process of the pharmacist}

Table 6 indicates the perceptions of the public regarding the consultation process of the pharmacist.

The high percentages of respondents (minimum 79.1\%) who perceived the various aspects of the pharmacist consultation as "very good", is clear evidence of patients' high esteem for the services provided by pharmacists.

Descriptive statistics relating to the average consultation time of the pharmacists (in minutes), and the time lapsed since the last consultation with the pharmacist on minor ailments (in months), are reflected in Table 7.

Given the positively skewed distribution of both the average consultation time (in minutes) and the time since the last consultation (in months) (characterised by a few large values), it is best to use the median as the measure of central tendency and it can thus be concluded that the average consultation time was five minutes and an average time of one month had lapsed since the last consultation with the pharmacist on minor ailments.

\section{Effectiveness of medication provided}

Table 8 indicates the patients' perception of the effectiveness of the medication provided by the pharmacist.

It is interesting to note that while approximately $90 \%$ of the respondents described the effectiveness as "very good", less than $60 \%$ held similar views regarding the cost of medicine.

Table 9 indicates the types of additional treatment required by participants for the same condition after a consultation with the pharmacist.

The fact that less than one in seven respondents indicated that they required additional medical treatment after a consultation with a pharmacist, is further evidence of the quality of the services provided by community pharmacists.

\section{Value of the pharmacist in health care}

The patients' perceptions about the value of the community pharmacist in the delivery of health care

Table 8: Patients' perception of effectiveness of medication provided

\begin{tabular}{|l|c|c|c|}
\hline Comments & $\begin{array}{c}\text { Yes, very } \\
\text { good }\end{array}$ & $\begin{array}{c}\text { Not } \\
\text { satisfactory }\end{array}$ & $\begin{array}{c}\text { No, not at } \\
\text { all }\end{array}$ \\
\hline Use of medication as explained & $97.0 \%$ & $3.0 \%$ & $0.0 \%$ \\
\hline Effectiveness of the medication & $93.9 \%$ & $6.1 \%$ & $0.0 \%$ \\
\hline Improvement of symptoms & $89.6 \%$ & $9.8 \%$ & $0.6 \%$ \\
\hline $\begin{array}{l}\text { Satisfaction with the cost of the medicine } \\
\text { provided }\end{array}$ & $57.9 \%$ & $23.8 \%$ & $18.3 \%$ \\
\hline
\end{tabular}

Table 9: Additional treatment needed after consultation with pharmacist

\begin{tabular}{|l|c|}
\hline \multicolumn{1}{|c|}{ Additional treatment needed } & Percentage (n=17) \\
\hline Additional medication & $94.1 \%$ \\
\hline Consultation - General Practitioner & $47.1 \%$ \\
\hline Consultation - Specialist & $5.9 \%$ \\
\hline Other medication due to wrong diagnosis & $5.9 \%$ \\
\hline
\end{tabular}


are reflected in Table 10. The statements in Table 10 are sorted in descending order according to the percentage "Totally agree" responses except for the negatively phrased statements (indicated by an * in the table) which were sorted on the percentage "Totally disagree" responses. The large percentages of participants who gave very positive responses were clear indicators of consumers' high regard for the services provided by community pharmacists.

\section{Choice of a specific pharmacy}

Participants indicated that they had used a particular pharmacy for a period ranging from one month to 40 years, with an average of 6.8 years based on the median value that was used due to the positive skewness of the data. The reasons indicated by the 162 participants for choosing a specific pharmacy are summarised in Table 11. Note that respondents could and did give two or more reasons, thus the sum of the percentages exceeds $100 \%$.

From Table 11 it is clear that by far the most important reason for using a specific pharmacy is its proximity.

\section{Summated scores}

The frequency distribution of the summated scores for sections $D, E$ and $F$ of the questionnaire are reported in Table 12. These scores were calculated to provide an overall score for various aspects of the services provided by pharmacists, that is consultation and effectiveness of general aspects respectively.

The large percentages of participants with very positive and positive perceptions (84.7\%, $97.5 \%$ and $82.2 \%$ ) for sections $D, E$ and $F$ were clear indicators of the positive consumer attitudes relating to the various as-

Table 10: Value of pharmacist in delivery of health care

\begin{tabular}{|l|c|c|c|c|}
\hline \multirow{2}{*}{ Statement } & \multicolumn{2}{|c|}{ Agree } & \multicolumn{2}{c|}{ Disagree } \\
\cline { 2 - 5 } & Totally & Sometimes & Sometimes & Totally \\
\hline $\begin{array}{l}\text { Pharmacists always deliver a very } \\
\text { professional service }\end{array}$ & $77.8 \%$ & $8.6 \%$ & $1.9 \%$ & $11.7 \%$ \\
\hline $\begin{array}{l}\text { My pharmacist(s) always delivers a } \\
\text { professional service }\end{array}$ & $76.4 \%$ & $8.1 \%$ & $3.7 \%$ & $11.8 \%$ \\
\hline $\begin{array}{l}\text { I have total faith in the competency and } \\
\text { drug-related knowledge of my pharmacist(s) }\end{array}$ & $75.0 \%$ & $9.4 \%$ & $3.1 \%$ & $12.5 \%$ \\
\hline I trust my pharmacist(s) a lot & $74.4 \%$ & $9.8 \%$ & $3.7 \%$ & $12.2 \%$ \\
\hline Pharmacists are always available for advice & $72.8 \%$ & $9.3 \%$ & $11.1 \%$ & $6.8 \%$ \\
\hline $\begin{array}{l}\text { Pharmacists play an important role in } \\
\text { delivering health care }\end{array}$ & $72.0 \%$ & $7.9 \%$ & $10.4 \%$ & $9.8 \%$ \\
\hline Pharmacies are always accessible & $70.8 \%$ & $11.2 \%$ & $9.9 \%$ & $8.1 \%$ \\
\hline $\begin{array}{l}\text { I don't need a pharmacist in my health care } \\
\text { management* }\end{array}$ & $14.8 \%$ & $6.8 \%$ & $10.5 \%$ & $67.9 \%$ \\
\hline $\begin{array}{l}\text { I don't want to see my pharmacist face-to- } \\
\text { face to get treatment from him/her* }\end{array}$ & $13.6 \%$ & $12.3 \%$ & $6.5 \%$ & $67.5 \%$ \\
\hline $\begin{array}{l}\text { I like the personal contact with my } \\
\text { pharmacist }\end{array}$ & $63.2 \%$ & $11.0 \%$ & $8.0 \%$ & $17.8 \%$ \\
\hline $\begin{array}{l}\text { Medicines available at a doctor and } \\
\text { supermarket are sufficient* }\end{array}$ & $26.4 \%$ & $13.5 \%$ & $17.8 \%$ & $42.3 \%$ \\
\hline * Negatively phrased statements & & & \\
\hline
\end{tabular}


pects of services rendered by pharmacists.

\section{DISCUSSION}

The South African health care industry is currently undergoing some major changes. These are all critical to the manner in which community pharmacies have been and will be operating in the future. Some of these external factors influencing community pharmacies are the following:

\section{Introduction of new pricing regulations (Act 101 of 1965)}

- This involved a change in the whole pricing structure of medicines as well as the remu- neration of health care professionals, including pharmacists.

- The disappearance of any bonus, sampling, discounts or any incentive schemes for providers and the public.

- This also entails the introduction of a fixed cost of medicine to the service providers, known as the Single Exit Price (SEP). The logistical fee for the distributors/wholesalers must be negotiated by themselves with the individual manufacturers.

- The previous mark-up system disappeared with the introduction of a maximum dispensing fee set by the Department of Health. The fee published by the Department of Health is currently in dispute by some role-players of the private

Table 11: Reasons for using the specific pharmacy

\begin{tabular}{|l|c|}
\hline Reason & Percentage \\
\hline Closest pharmacy to work or home & $64.2 \%$ \\
\hline Like the services rendered & $36.4 \%$ \\
\hline Cheapest pharmacy & $33.3 \%$ \\
\hline Know the pharmacist for years & $18.5 \%$ \\
\hline Familiar with employees & $15.4 \%$ \\
\hline Render specialised services (for example, clinic) & $8.0 \%$ \\
\hline Keep specialised products & $4.3 \%$ \\
\hline Only pharmacy available in town & $4.3 \%$ \\
\hline Preferred provider (Designated Service Provider or DSP) for medical aid & $3.7 \%$ \\
\hline Like the pharmacy lay-out & $3.1 \%$ \\
\hline Referred to pharmacy by other individuals & $2.5 \%$ \\
\hline Consultation from doctor too expensive & $1.9 \%$ \\
\hline Service quicker & $1.2 \%$ \\
\hline Use different pharmacies all the time & $1.2 \%$ \\
\hline Delivery service available & $0.6 \%$ \\
\hline Limited options available in town & $0.6 \%$ \\
\hline
\end{tabular}

Table 12: Frequency distribution of Sections D Consultation, E Medication and F Pharmacist and Pharmacy

\begin{tabular}{|l|c|c|c|c|c|}
\hline \multicolumn{1}{|c|}{ Score } & Very Positive & Positive & Negative & Very Negative & Total \\
\hline DScore & $138(84.7 \%)$ & $0(0.0 \%)$ & $20(12.3 \%)$ & $5(3.1 \%)$ & $163(100 \%)$ \\
\hline EScore & $158(97.5 \%)$ & $0(0.0 \%)$ & $4(2.5 \%)$ & $0(0 \%)$ & $162(100 \%)$ \\
\hline FScore & $119(73.0 \%)$ & $15(9.2 \%)$ & $12(7.4 \%)$ & $17(10.4 \%)$ & $163(100 \%)$ \\
\hline
\end{tabular}


sector. The Constitutional Court ruled that the dispensing fee is not appropriate. The Pricing Committee was ordered to revisit the dispensing fee. In the meantime, there are no clear criteria set to guide the community pharmacist.

- As can be imagined, a significant number of media discussions and debates (both positive and negative) are directed at community pharmacies. This leads to oversensitivity towards the price of medication, in the light of cheaper products publicly promised to the patients.

\section{Licensing of dispensing doctors by the Department of Health}

- With the implementation of the new Medicine Act (101 of 1965), dispensing doctors needed to apply for a licence to be able to dispense.

- There was an unsuccessful appeal by the doctors in court against this licensing process. They need to apply for a dispensing licence, and this also created extensive media attention. Doctors' dispensing is also highlighted and is a very sensitive issue in the public's mind at this point in time.

- With the pricing regulations published, doctors were also awarded a lower dispensing fee, since it is not their primary business. This can also be perceived by patients to be an advantage because it is lower than for pharmacies.

The reason for conducting this survey with two samples is to see if any of these issues will have an effect on the perceptions of the patients. The second survey will be done after the market has settled down and the pharmaceutical industry is again more stable. The most important limitations of this study were the relatively small sample size, the fact that only individuals listed in telephone directories were contacted, and that only English was used in the telephone survey. Results were therefore not analysed according to language or gender groups, racial groups, or urban versus rural location of respondents. These factors could be investigated in a more comprehensive study.

\section{CONCLUSION AND RECOMMENDA- TIONS}

This survey indicated that the majority (54.8\%) of patients were using the community pharmacist for the treatment of minor ailments. The most important reasons given by participants for not using the pharmacist were that participants used a doctor $(67.9 \%)$, the clinic $(55.2 \%)$ or supermarkets $(10.4 \%)$ to obtain their OTC medication. Another reason was that participants regarded pharmacies as too expensive (21.6\%) or that they needed a prescription to submit a claim to their medical aid (20.1\%), so they needed to consult a doctor.

When the patient consulted the pharmacist for minor ailments the indication was clear (average 83.3\%) that the patients perceived the pharmacist's consultation as very thorough, asking the patient all the relevant questions and also providing the patient with all the necessary information regarding the medicines as well as clear directions for the effective use of these products. A negligible $1.9 \%$ of the patients were of the opinion that the diagnosis by the pharmacist was not accurate.

Regarding the effective recommendation of the medication and adequate directions for the correct use thereof, $93.5 \%$ of the patients were satisfied. On the price of medicines there was a clear indication that $18.3 \%$ of the patients were completely dissatisfied with the price of medicines.

Only $13.0 \%$ of the patients consulted by a community pharmacist needed additional therapy for the same condition after their consultation, of which $94.1 \%$ required additional medication.

Regarding the perceptions of the patients about the role of and value added by community pharmacists, $82.4 \%$ of the participants obtained a positive summated score for the questions in section $\mathrm{F}$ relating to various aspects of the service provided by community pharmacists. It can thus be concluded that approximately four out of every five participants who made use of a pharmacist for treating minor conditions agreed about the added value and the important role that the community pharmacist played in their health care. 
The most important reason why participants used a specific pharmacy was found to be proximity from home or work (64.2\%). Other reasons were an appreciation of the services that the pharmacy is rendering (36.4\%) and the fact that the specific pharmacy was the cheapest (33.3\%).

The impact of the relevant issues relating to new legislation affecting the pharmaceutical industry and the dispensing of medicine resulted in greater public awareness. The implications of these issues need to be explained to the public, so that they can fully understand the impact of these developments. It is recommended that further studies be conducted, so that the perception of the pharmacists' role can be monitored continuously.

\section{ACKNOWLEDGEMENT}

Mr FE Potgieter for his assistance in the telephone survey.

\section{REFERENCES}

ALSOBROOK, HB 1992: An overview of liability for OTC drugs. Drug Information Journal, 26(3):317-328.

BELL, J 1990: A Pharmacy based self-care programme - the Australian experience. Journal of Social and Administrative Pharmacy, 7(4):221-225.

BERGER, K; EICKHOFF, C \& SCHULZ, M 2005: Counselling quality in community pharmacies: Implementation of the pseudo customer methodology in Germany. Journal of Clinical Pharmacy and Therapeutics, 30(1):45-57.

BEZOLD, C 1990: Future trends in self-medication and self-care. Journal of Social and Administrative Pharmacy, 7(4):205215.

BRADLEY, C \& BLENKINSOPP A 1996: Over the counter drugs: The future for self medication. British Medical Journal, 312(7034): 835-837.

CHUI, WK \& LI, SC 2005: Advice-giving on self-medication: Perspectives of community pharmacists and consumers in Singapore. Journal of Clinical Pharmacy and Therapeutics, 30(3):225-231.

DREYER, AC; SERFONTEIN, JH; VAN DER MEER, HL \& WAGNER, $S$ 1999: Cost savings effected by community pharmacists' interventions in the supply of medicines in the Republic of South Africa. Journal of Research in Pharmaceutical Economics, 9(4):1-20.

GOOD PHARMACY PRACTICE IN SOUTHAFRICA 2004: $2^{\text {nd }}$ edition.
Arcadia: The South African Pharmacy Council.

KRISHMAN, HS \& SCHAEFER, M 2000: Evaluation of the impact of pharmacist's advice giving on the outcomes of self-medication in patients suffering from dyspepsia. Pharmacy World and Science, 22(3):102-108.

LEVIN, LS 1990: Reorienting perspectives on self-medication. Journal of Social and Administrative Pharmacy, 7(4):150155.

LUNDE, I 1990: Self-care: What is it? Journal of Social and Administrative Pharmacy, 7(4):150-155.

LUNDE, I \& DUKES, G 1989: The role and function of the community and hospital pharmacist in the health care systems of Europe: Report of a WHO working group and recommendations of a meeting convened by the World Health Organisation's Regional Office for Europe, Madrid 29 November - 1 December 1988. WHO: Styx Publications.

McELNAY, J \& McCALLION, CR 1996: Non-prescription drug use by elderly patients. International Journal of Pharmacy Practice, 4(1):6-11.

MEDICINES AND RELATED SUBSTANCES ACT 101 of 1965: (In: PSSA Pharmacy Law Compendium, Volume 1. Service Issue 1 as at 30 June 2003. Durban: Lexis Nexis Butterworths).

MUKERJEE, D \& BLANE, DB 1990: Pharmaceutical service delivery by community pharmacies in areas of contrasting medical provision. Social Science and Medicine, 31(11):1277-1280.

ONG, P 1990: Pharmacies - the people's choice for self-medication. Journal of Social and Administrative Pharmacy, 7(4):225-226.

PHARMACY ACT 53 of 1974: (In: PSSA Pharmacy Law Compendium, Volume 1. Service Issue 1 as at 30 June 2003. Durban: Lexis Nexis Butterworths).

REEKIE, DW \& SCOTT, DR 1988: South African Health care and the proprietary medicine industry. South African Medical Journal, 74(5):205-208.

REGULATIONS RELATING TO THE REGISTRATION OF PERSONS AND THE MAINTENANCE OF REGISTERS GNR. 1160 of 20 November 2000 Regulations to the Pharmacy Act 53 of 1974 (In: PSSA Pharmacy Law Compendium, Volume 1. Service Issue 1 as at 30 June 2003. Durban: Lexis Nexis Butterworths).

SMITH, F 1996: Referral of clients by community pharmacists: Views of general medical practitioners. International Journal of Pharmacy Practice, 4(1):30-35.

VAN DER GEEST, S \& HARDON, A 1990: Self-medication in developing countries. Journal of Social and Administrative Pharmacy, 7(4):199-204. 


\section{Appendix A}

\section{Public Perception Form}

\begin{tabular}{|l|l|r|r|r|r|}
\hline \multicolumn{7}{|c|}{ Part 1 } \\
\hline A. Demographics of Respondent & 2. Age & Years & \\
\hline 1. Gender & Male & Female & 2 & & \\
\hline 3. Highest Education & Pre-school & $<$ grade 6 & $<$ grade 12 & grade 12 & Diploma / degree \\
\hline
\end{tabular}

\section{B: Medical Aid and OTC}

1. Do you have a medical aid?

\begin{tabular}{l|c|c|} 
2. If YES - does your medical aid have an over-the-counter (OTC) option that you use? & Yes & No
\end{tabular}

\begin{tabular}{l|l|l|l|l} 
3. If YES - how often do you use the OTC service? & never & sometimes & often & always
\end{tabular}

C. Use of Community Pharmacy

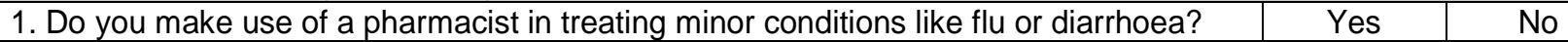

IF YES - GO TO Part 2

IF NO - answer the following questions.

2. Why don't you make use of the OTC service that pharmacists render to the public?

2.1 Don't have access to a pharmacy

2.2 Too expensive

2.3 Get my medication from the supermarket

2.4 Get my medication from the doctor

2.5 Get my medication from the clinic

2.6 Get my medication from a traditional healer

2.7 Don't like a pharmacist

2.8 Don't see it as part of the scope of practice of a pharmacist

2.9 Get it on my medical aid - need a prescription to claim

2.10 Other - specify

\section{End of questionnaire if pharmacists not used}

\section{Part 2}

If you think back to the last time you consulted a pharmacist for OTC medication - how would you rate

the following:

D. Consultation

Was the correct diagnosis made?

2. Were you explained how to use the medication?

3. Were you asked about any chronic conditions?

4. Were you asked about any medication currently used?

5. Were you asked about any allergies?

6. Were the side effects discussed with you?

7. Were any special precautions explained to you?

8. Were you told to see the doctor if the symptoms persist?

9. How long did the consultation take in total?

10. How long ago did the consultation take place?

\begin{tabular}{|c|c|c|}
$\begin{array}{c}\text { Yes, very } \\
\text { good }\end{array}$ & $\begin{array}{c}\text { Not } \\
\text { satisfactory }\end{array}$ & $\begin{array}{c}\text { No, not at } \\
\text { all }\end{array}$ \\
\hline 1 & 2 & 3 \\
\hline 1 & 2 & 3 \\
\hline 1 & 2 & 3 \\
\hline 1 & 2 & 3 \\
\hline 1 & 2 & 3 \\
\hline 1 & 2 & 3 \\
\hline 1 & 2 & 3 \\
\hline 1 & 2 & 3 \\
\hline
\end{tabular}

\section{E. Medication}

1. Were you satisfied with the cost of the medicine provided?

2. Do you believe that the medication provided were effective?

3. How would you describe the improvement of your symptoms?

4. Did you use the medication exactly as explained?

minutes

months

5. Did you need any other medical treatment afterwards for the same condition?

6. If yes, specify:

6.1 Other medication due to wrong diagnosis

6.2 Additional medication

6.3 Consultation - General Practitioner

6.4 Consultation - Specialist

\begin{tabular}{|c|c|}
\hline $\begin{array}{c}\text { Yes, very } \\
\text { good }\end{array}$ & $\begin{array}{r}\text { satis } \\
\text { soo }\end{array}$ \\
\hline 1 & \\
\hline 1 & \\
\hline 1 & \\
\hline
\end{tabular}

No, not at

all

\begin{tabular}{|l|l|}
\hline 2 & 3 \\
\hline 2 & 3 \\
\hline 2 & 3 \\
\hline 2 & 3
\end{tabular}




\section{Appendix A}

\section{F. Pharmacists \& Pharmacies}

Please indicate to what extent you agree with the following statements:
Totally agree (1)
Sometimes Agree (2)
Sometimes disagree (3)
Totally disagree (4)

1. Pharmacists play an important role in delivering health care

2. Pharmacists are always available for advice

3. I like the personal contact with my pharmacist

4. I don't need a pharmacist in my health care management

5. Medicines available at a doctor and supermarket are sufficient

6. Pharmacies are always accessible

7. I trust my pharmacist(s) a lot

8. I don't want to see my pharmacist face-to-face to get treatment from him/her

9. I have total faith in the competency and drug-related knowledge of my pharmacist(s)

10. Pharmacists always deliver a very professional service

11. My pharmacist(s) always delivers a professional service

\begin{tabular}{|l|l|l|l|}
\hline 1 & 2 & 3 & 4 \\
\hline 1 & 2 & 3 & 4 \\
\hline 1 & 2 & 3 & 4 \\
\hline 1 & 2 & 3 & 4 \\
\hline 1 & 2 & 3 & 4 \\
\hline 1 & 2 & 3 & 4 \\
\hline 1 & 2 & 3 & 4 \\
\hline 1 & 2 & 3 & 4 \\
\hline 1 & 2 & 3 & 4 \\
\hline 1 & 2 & 3 & 4 \\
\hline 1 & 2 & 3 & 4 \\
\hline
\end{tabular}

12. How long have you been using the pharmacy that you last visited for OTC medication?

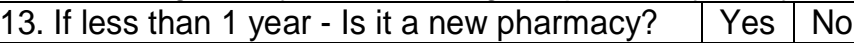

14. Why did you choose that specific pharmacy?

14.1 Familiar with employees

14.2 Know the pharmacist for years

14.3 Closest pharmacy to work or home

14.4 Like the services rendered

14.5 Cheapest

14.6 Preferred provider with medical aid

14.7 Like the pharmacy lay-out

14.8 Keep specialized products

14.9 Render specialized services (e.g. clinic)

14.10 Other, please specify: 